\title{
WATER-SOLUBLE CATIONIC CELLULOSE COUPLED TO A ULTRAFILTRATION MEMBRANE FOR THE REMOVAL OF ARSENIC AND CHROMIUM
}

\author{
JULIO SÁNCHEZ1, LEANDRO TOLEDO ${ }^{1}$, BERNABÉ L. RIVAS ${ }^{* 1}$, NANCY RIVERA2 , EFRÉN MUÑOZ \\ 1) Polymer Department, Faculty of Chemistry, University of Concepción, Casilla 160-C, Concepción, Chile. \\ 2) Pedagogical and Technological University of Colombia (UPTC), Colombia
}

(Received: July 12, 2013 - Accepted: October 2, 2013)

\begin{abstract}
This article describes the retention properties of arsenic (V) and chromium (VI) using a water-soluble polymer based on cationic hydroxyethylcellulose and combined with an ultrafiltration membrane. The polymer was purchased commercially and was characterized by Fourier transform infrared spectroscopy (FTIR). The study of polymer removal capacity of $\mathrm{As}(\mathrm{V})$ and $\mathrm{Cr}(\mathrm{VI})$ were performed by liquid-phase polymer-based retention technique (LPR). By means of a washing method studied retention as a function of $\mathrm{pH}$, the amount of polymer, and the concentration of $\mathrm{As}(\mathrm{V})$ and $\mathrm{Cr}(\mathrm{VI})$.

The results showed that the retention capacity of both oxy-anions increases with the solution $\mathrm{pH}$. Due to the presence of quaternary ammonium groups in the polymer structure, the retention of $\mathrm{As}(\mathrm{V})$ and $\mathrm{Cr}(\mathrm{VI})$ was higher at a $\mathrm{pH}$ of 9 than that at acidic $\mathrm{pH}$ levels, reaching values of $65 \%$ for $\mathrm{Cr}(\mathrm{VI})$ and $43 \%$ for $\mathrm{As}(\mathrm{V})$. The study in function of amount of polymer showed that using $75 \mathrm{mg}$ the retention of $\mathrm{As}(\mathrm{V})$ was $65 \%$. In the case of $\mathrm{Cr}(\mathrm{VI})$ using $50 \mathrm{mg}$ of polymer, $67 \%$ retention was obtained. Using low concentrations for arsenic and chromium, maximum retention was found at $65 \%$ and $95 \%$, respectively.

The maximum retention capacity (MRC) of the polymer was determined by adding $\mathrm{As}(\mathrm{V})$ and $\mathrm{Cr}(\mathrm{VI})$ to the polymer solution and concentrating in successive steps. FTIR spectra before and after of retention showed differences by the interaction with oxy-anions.
\end{abstract}

Keywords: Cellulose, Contaminants, Polymers, Membranes, Ultrafiltration.

\section{INTRODUCTION}

Cellulose is the most abundant natural polymer and the most available worldwide renewable resource [1]; however, its use in different fields is restricted by limitations arising from its structure, given that the melting point of cellulose is higher than the temperature at which it begins to deteriorate. For that reason, using a cellulose solution is the only way to manufacture usable materials [2]. Cellulosic materials are insoluble, safe for living organisms, reproducible, recyclable and biodegradable. Many technologies have been used to produce cellulosic materials modified for daily necessities and industrial use [3]. Chemical modification or functionalization of natural or synthetic polymers seeks to improve properties such as affinity for one or more ions, and for environmental applications, selectivity for metal ions [4-6]. Recently, the hydroxy ethyl cellulose has been modified with quaternary ammonium monomers, resulting in a cationic polymer based on cellulose with optimum viscosity [7]. This is a highly modified polymer used in the manufacture of hair care products because of its exceptional power to restore damaged hair and improve the wettability, appearance, and feel of dry hair. These polymers are also compatible with a wide range of surfactant systems. In recent years, scientists have expressed interest in the study of the solution properties and adsorption behavior of these cellulosics polymers [8]. Furthermore, due to metal ions are the most dangerous water contaminants and their concentration are continuously increasing $[4,9,10]$.

Arsenic and chromium are some of the most common contaminants found in the industrial sector. These metals may be toxic to organisms, even at low concentrations [11].

Currently there are several technologies for removing arsenic and chromium which employ membranes or polymeric materials, including reverse osmosis, nano-processes, micro-and ultrafiltration, ion exchange resins and water-soluble polymers [12]. It has been found that the combination of ultrafiltration and water soluble polymers is an efficient technique for the removal of ions as long as there is a suitable metal-polymer interaction $[4,13]$. In the system of ultrafiltration, the membrane acts as a barrier of molecular size; however, the pore size is too large to retain metal ions without their being in colloidal form [14]. The formation of polymer-metal species of high molecular weight leads to the retention of metal ions $[14,15]$. The LiquidPhase Polymer-based Retention (LPR) technique is based on this principle. The great advantage of this technique is that it can be carried out in homogeneous media largely avoiding the phenomenon of mass transfer or diffusion which occurs in heterogeneous methods [12, 16-18].

The present study focuses on the removal of chromate and arsenate ions using a commercial water-soluble cationic hydroxy ethyl cellulose and combining it with ultrafiltration (UF) membranes. Retention capabilities of arsenic and chromium were studied with cationic cellulose and the LPR technique using a washing method. The maximum retention capacity (MRC) of the polymer was determined by adding $\mathrm{As}(\mathrm{V})$ and $\mathrm{Cr}(\mathrm{VI})$ to the polymer solution and concentrating in successive steps.

\section{EXPERIMENTAL}

Quaternized hydroxyl ethyl cellulose ethoxylate (QHECE) was from Sigma-Aldrich. Figure 1 shows the structure of the QHECE.

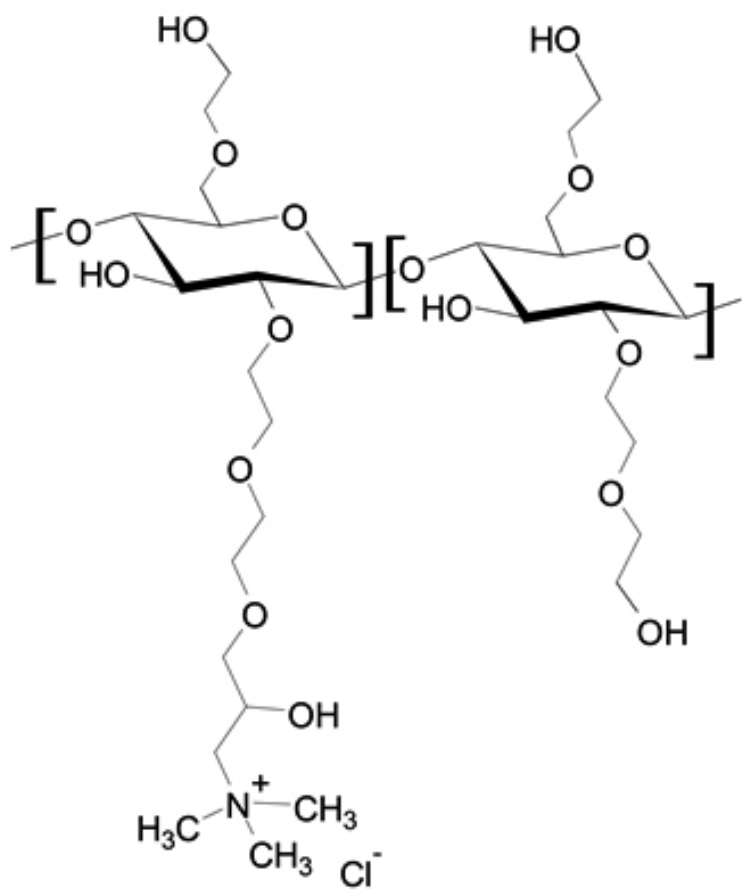

Figure 1. Chemical structure idealized of (QHECE). 
2.1 Characterization of the polymer by Fourier Transform Infrared (FTIR) Spectroscopy

The characterization was carried out by FTIR spectroscopy before and after determining the maximum retention capacity of $\mathrm{As}(\mathrm{V})$ and $\mathrm{Cr}(\mathrm{VI})$. FTIR analysis was performed using a Nicolet Magna 550 spectrometer and a Nicolet Nexus. For the quantitative analysis, $1 \mathrm{mg}$ of the sample per $100 \mathrm{mg}$ of $\mathrm{KBr}$ was used. FTIR studies were conducted in the range of $400-4000 \mathrm{~cm}^{-1}$.

\subsection{Ultrafiltration procedure}

The main features of the LPR system include a ultrafiltration cell (Amicon 8050 ) with a magnetic stirrer containing a polyethersulfone membrane with a molecular weight cut-off of 10,000 Da (Millipore), a reservoir (Amicon RC800), a selector, and a nitrogen gas cylinder as the pressure source (see Fig. 2).

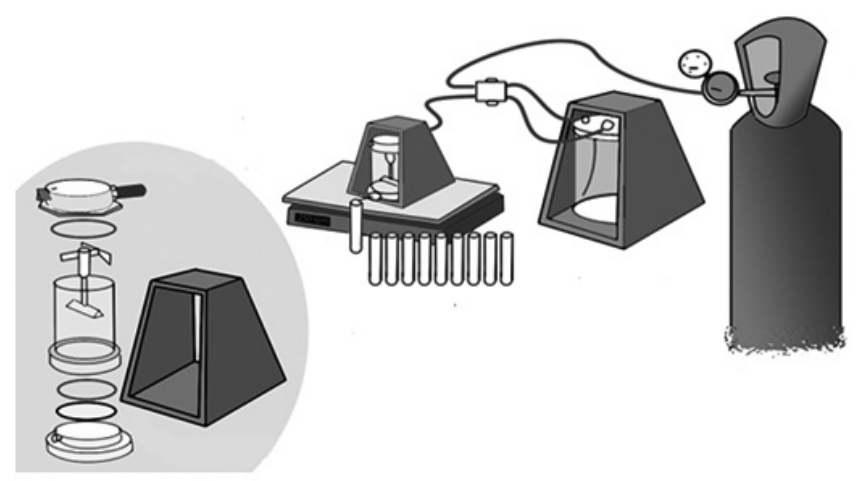

Figure 2. Equipment used for LPR

In this study, two different modes of LPR were used to remove arsenates and chromates. The first one was the washing method, which is a batch-like procedure in which the polymer is dissolved in deionized water and another solution is added to it. This procedure was performed with an arsenic and chromium solution, separately. Afterward, washing was performed with water adjusted at $\mathrm{pH} 3$ and 9 in a separate experiment, by adding $0.1 \mathrm{~mol} / \mathrm{L}$ $\mathrm{HNO}_{3}$ or $\mathrm{NaOH}$ accordingly. The $\mathrm{pH}$ value was measured by a $\mathrm{pH}$ meter 330 Inolab WTW. The resulting polymer-metal mixture was stirred for $1 \mathrm{~h}$ at room temperature and then placed in the ultrafiltration cell. The solution was introduced to the ultrafiltration cell and washed with reservoir water at the same $\mathrm{pH}$. All studies were performed under a total pressure of 3.5 bar at room temperature. The total volume $(20 \mathrm{~mL})$ in the cell was kept constant and measurements of $20 \mathrm{~mL}$ were collected by filtration up to a total volume of $100 \mathrm{~mL}$. Results of the $\mathrm{Cr}(\mathrm{VI})$ or $\mathrm{As}(\mathrm{V})$ uptake are systematically presented as the percentage of retention $\mathrm{R}(\%)$ versus the volume of permeate. The washing method was performed in a blank experiment (in the absence of the soluble polymer) which was included in order to evaluate the interaction of the membrane with oxy-anions.

The second method presented in this paper is the enrichment method, which determines the maximum retention capacity of the polymer. The experiment was performed as follows: initially $250 \mathrm{mg}$ of polymer was dissolved in 30 $\mathrm{mL}$ of solution containing $75 \mathrm{mg} / \mathrm{L}$ of oxy-anions at a $\mathrm{pH} 9$, then, the volume was concentrated to $20 \mathrm{~mL}$, collecting $10 \mathrm{ml}$ of filtrate. This procedure was performed in successive steps, collecting a total volume of $130 \mathrm{~mL}$ of filtrate. Final concentration in the filtrate was measured. The enrichment experiments for $\mathrm{Cr}(\mathrm{VI})$ and $\mathrm{As}(\mathrm{V})$ were done separately.

After retention experiments, chromium and arsenic concentrations were measured in the filtrate by Atomic Absorption Spectroscopy (AAS) using a Perking Elmer 3100 spectrometer.

\section{RESULTS AND DISCUSSION}

\subsection{Effect of $\mathrm{pH}$ on the retention of $\mathrm{Cr}(\mathrm{VI})$ and $\mathrm{As}(\mathrm{V})$}

Chromium can exist in several oxidation states, ranging from 2 to 6 . In nature, the most common and stable in water are $\mathrm{Cr}_{2} \mathrm{O}_{7}^{2-}, \mathrm{HCrO}_{4}^{-}$and $\mathrm{CrO}_{4}^{2-}$, depending on the solution $\mathrm{pH}$ and the concentration. At a pH of smaller than 1 , the predominant species is chromic acid $\left(\mathrm{H}_{2} \mathrm{CrO}_{4}\right)$. At $\mathrm{pH}$ ranges between 2 and 4, it exists mainly in the form of dichromate, $\mathrm{Cr}_{2} \mathrm{O}_{7}^{2-}$ in equilibrium with $\mathrm{HCrO}_{4}^{-}$ions. Under alkaline conditions $(\mathrm{pH} 8)$ it exists predominantly as chromate anion $\left(\mathrm{CrO}_{4}^{2-}\right)[19,20]$.
Arsenic exists in oxidation states $-3,0,3$ and 5 [21]. The most common forms that may be found in natural waters are arsenates: $\mathrm{H}_{2} \mathrm{AsO}_{4}^{-}(\mathrm{pH} 2-7)$, $\mathrm{HAsO}_{4}^{2-}(\mathrm{pH} 7-12)$ and $\mathrm{AsO}_{4}^{3-}(\mathrm{pH}>12)$.

The study of the effect of $\mathrm{pH}$ on the retention of arsenic and chromium was performed at $\mathrm{pH} 3$ and 9 . The adjustment of $\mathrm{pH}$ was carried out both in cell and in the water reservoir. Blank analyses, those without water-soluble polymers were conducted to determine the effect of the membrane in the removal of the oxy-anions. The results showed that the membrane does not retain ions of $\mathrm{Cr}(\mathrm{VI})$ or $\mathrm{As}(\mathrm{V})$ at either of the $\mathrm{pH}$ levels studied. The results regarding the effect of $\mathrm{pH}$ show that the retention capacity of both anions increases with the solution $\mathrm{pH}$. At $\mathrm{pH} 3$, the retention capacity of arsenate and chromate ions decreases and is negligible at $100 \mathrm{~mL}$ of filtered solution (see Fig. 3). Due to the presence of quaternary ammonium groups in the polymer structure, at $\mathrm{pH}$ 9 the retention of $\mathrm{Cr}(\mathrm{VI})$ and $\mathrm{As}(\mathrm{V})$ was higher than that at an acidic $\mathrm{pH}$, reaching values of $65 \%$ for $\mathrm{Cr}$ (VI) and $43 \%$ for As (V) (see Fig. 3). This is mainly due to the speciation of chromate and arsenate as a function of $\mathrm{pH}$. At acidic $\mathrm{pH}$ levels these species are monovalent anions, whereas at basic $\mathrm{pH}$ levels both species are divalent ions.
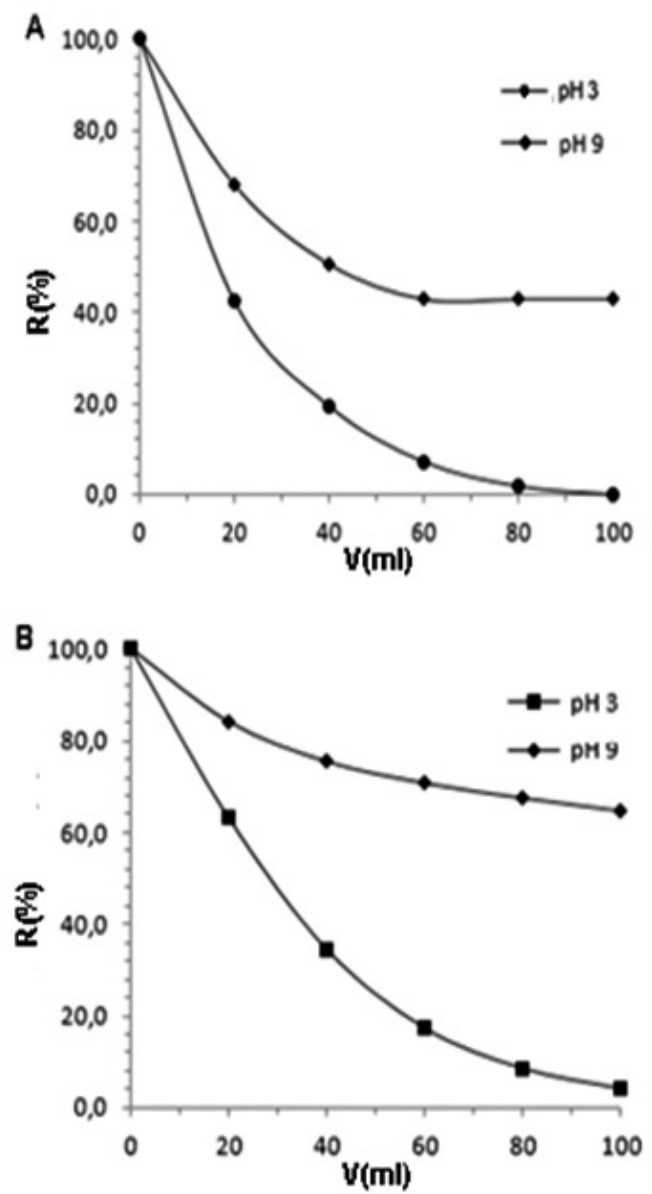
of $\mathrm{pH}$

Figure 3. Retention profile of A) arsenic and B) chromium as a function

\subsection{Study of the amount of polymer in retention}

Using the washing method, the removal of chromium (VI) and arsenic (V) was optimized by varying the amount of polymer at $\mathrm{pH} 9$. In the ultrafiltration cell the amount of polymer was varied $(25,50$ and $75 \mathrm{mg})$ maintaining constant the concentration of chromium and arsenic $(30 \mathrm{mg} / \mathrm{L})$. Figure 4 shows that the retention of arsenic increases with increasing the amount of polymer. In contrast, the retention of chromium does not have the same tendency. In the case of $\mathrm{Cr}(\mathrm{VI})$, using $50 \mathrm{mg}$ of polymer, $67 \%$ retention was obtained. The results for $\mathrm{As}(\mathrm{V})$ showed that using $75 \mathrm{mg}$, retention was $65 \%$.

In the case of arsenic, the retention rate remains constant from $60 \mathrm{~mL}$ of filtered liquid. However, the percentage of retention of chromium decreases 
continuously to $100 \mathrm{~mL}$ of filtered solution.

Differences in arsenic and chromium retention may be due to conformational changes of the polymer, which influences the electrostatic interactions between the cationic polymer and the anion to be removed $[4,13]$
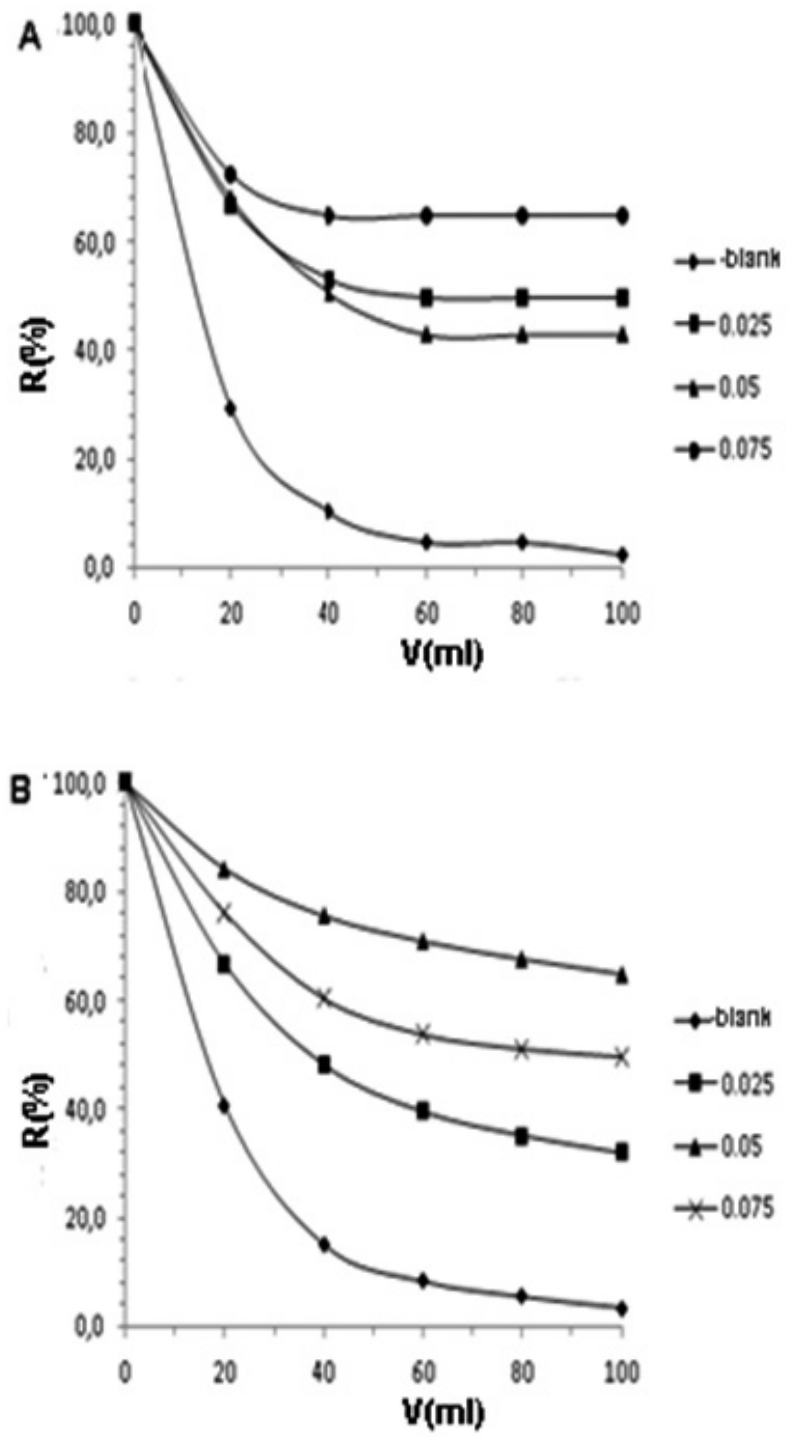

Figure 4. Retention profile of A) arsenic and B) chromium at $\mathrm{pH} 9$ as a function of the amount of polymer.

3.3 Effect of the concentration of $\mathrm{As}(\mathrm{V})$ and $\mathrm{Cr}(\mathrm{VI})$ in retention

Considering the optimum amount of polymer previously determined $(75 \mathrm{mg}$ for $\mathrm{As}(\mathrm{V})$ and $50 \mathrm{mg}$ for $\mathrm{Cr}(\mathrm{VI})$ ), we analyzed the influence of the concentration of $\mathrm{As}(\mathrm{V})$ and $\mathrm{Cr}(\mathrm{VI})$ in retention. Experiments were performed using different concentrations $(15,30$ and $60 \mathrm{mg} / \mathrm{L})$ of $\mathrm{As}(\mathrm{V})$ and $\mathrm{Cr}(\mathrm{VI})$ in the feed. This study showed that the removal capacity increased, as the concentration of oxy-anions in the cell was lower $(15 \mathrm{mg} / \mathrm{L})$ (see Fig. 5). The effect of the conformational changes must be taken into account, or distance between neighboring groups of the polymer chains can affect the results. In addition, the filtration of ions and their subsequent release from the polymer induces an increase in the net charge on the polymer surface, followed by the expansion of the chains, increasing the total surface, which minimizes the electrostatic repulsion due to low ion concentration [22]. The retention of $\mathrm{As}(\mathrm{V})$ peaked at $65 \%$, and for $\mathrm{Cr}(\mathrm{VI})$ maximum retention was $95 \%$.
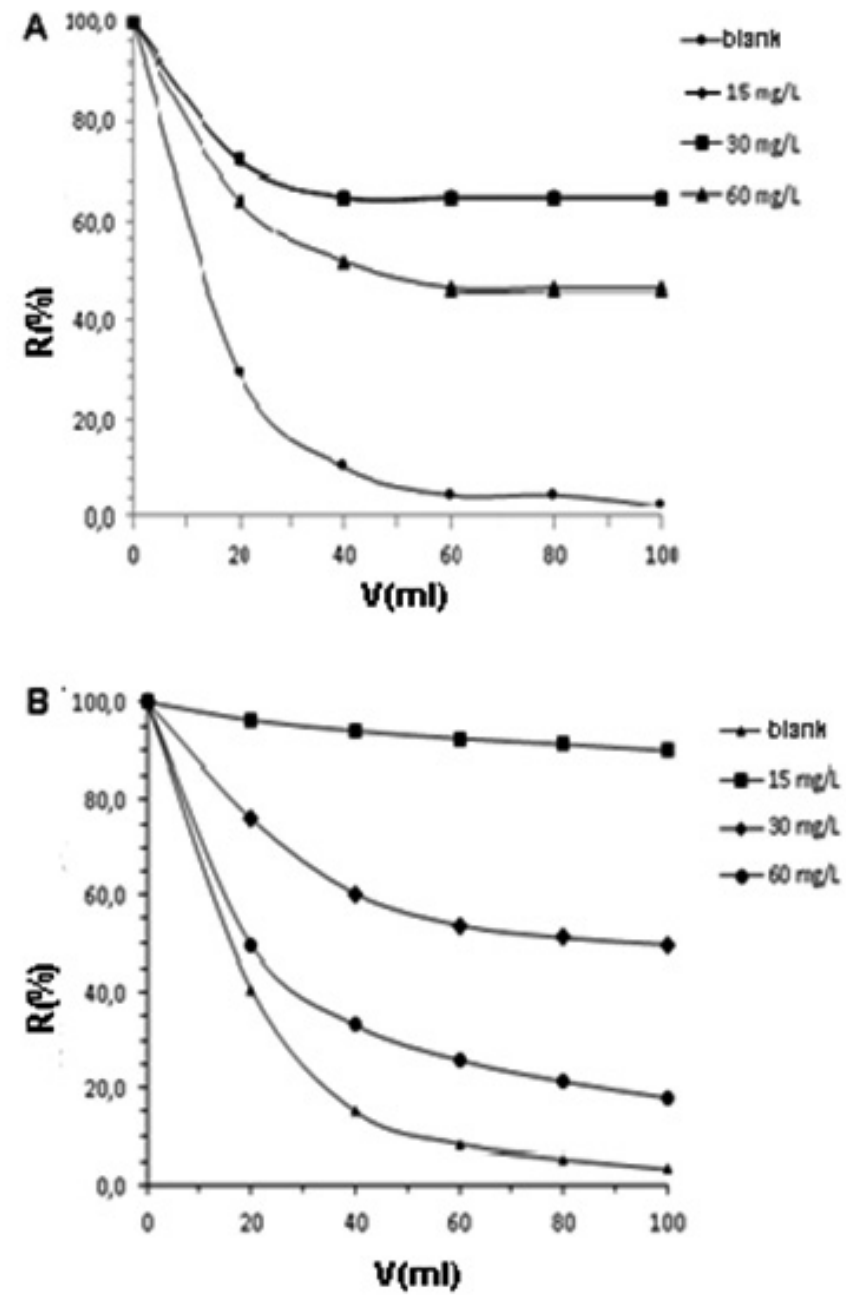

Figure 5. Retention profile as a function of the concentration of A) arsenic and B) chromium.

\subsection{Effect of variables in the flux}

The experiments were performed using a polyethersulfone membrane which is hydrophobic and does not retain water, thus generating a faster flow. In Figure 6 (A) the flux profiles show that the meanwhile there is more polymer, more time is needed to filter the same volume. Comparing the flux profile in figure 6 (B), it can be seen that the times are relatively similar between $\mathrm{Cr}(\mathrm{VI})$ and $\mathrm{As}(\mathrm{V})$ oxy-anions at different concentrations with the same amount of polymer. It was expected that the flow would be constant, as the pressure is always the same; but according to the literature, the polymer can cause a fouling effect, and this may be because the polymer is deposited on the surface of the membrane [23]. Likewise, the structure of the polymer may be involved in this effect, thus causing a decrease in the flow. Variations in the polymer concentration allowed observing this fouling effect. This can be attributed to interactions between the polymer and the membrane.

\subsection{Maximum retention capacity using the enrichment method}

The enrichment experiment was carried out to determine the MRC of the polymer reaching the saturation in successive steps. Figure 7 shows the concentration of $\mathrm{As}(\mathrm{V})$ and $\mathrm{Cr}(\mathrm{VI})$ in the filtrate versus the volume filtered. The retention of arsenic and chromium is equivalent in the first $20 \mathrm{~mL}$ of filtrate $(90 \%)$. Above $30 \mathrm{~mL}$ a different trend was observed, showing increased retention of arsenic compared to chromium, over the entire all range of the filtrate volume, eventually reaching a saturation and retention rate of $38 \%$ for arsenic and $14 \%$ for chromium at $130 \mathrm{~mL}$ of filtrate. 

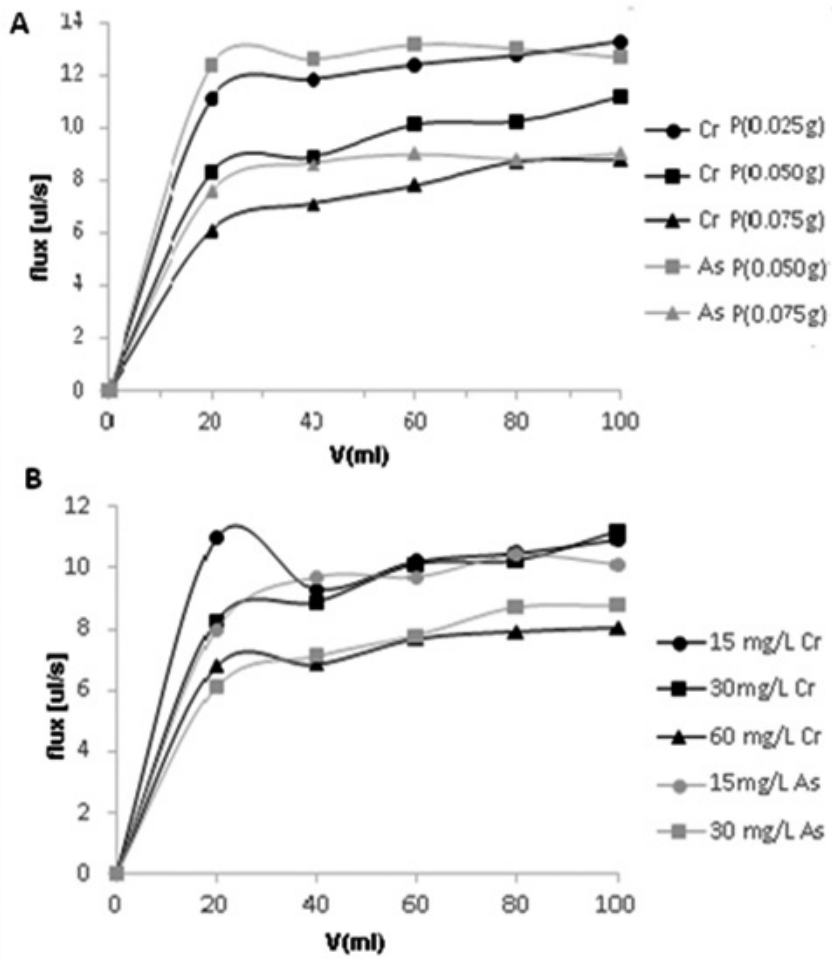

Figure 6. Flow profile for $\mathrm{Cr}(\mathrm{VI})$ and $\mathrm{As}(\mathrm{V})$ using membrane poly(ethersulfone), as a function of A) amount of polymer and B) concentration of oxy-anions.

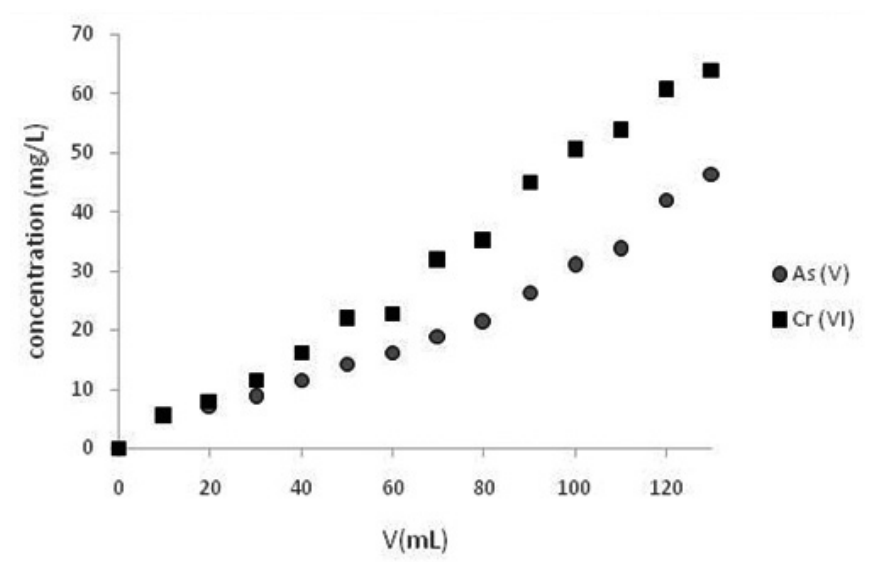

Figure 7. Maximum retention capacity of $\mathrm{As}(\mathrm{V})$ and $\mathrm{Cr}(\mathrm{VI})$ using $\mathrm{HEC}-\mathrm{E}$ at $\mathrm{pH} 9$.

\subsection{Fourier Transform-Infrared (FT-IR) Spectroscopy}

The main absorption bands (in $\mathrm{cm}^{-1}$ ) of the polymer are: $3436 \mathrm{~cm}^{-1}(-\mathrm{OH})$, 2920 and $2880 \mathrm{~cm}^{-1}\left(-\mathrm{CH}_{3},-\mathrm{CH}_{2}\right)$. The absorption bands at 1478 and $930 \mathrm{~cm}^{-1}$ correspond to the $\mathrm{C}-\mathrm{N}$ vibration of the quaternary ammonium. The peak levels of absorption between 1000 and $1250 \mathrm{~cm}^{-1}$ correspond to the presence of ether (C-O-C).

Following the addition of $\mathrm{Cr}(\mathrm{VI})$ and $\mathrm{As}(\mathrm{V})$ the increasing band at 1380 $\mathrm{cm}^{-1}$ from chromate and arsenate groups corresponding to $v(\mathrm{Cr}=\mathrm{O})$ and $v(\mathrm{As}$ $=\mathrm{O}$ ).

The appearance of a new bands at 860 and $885 \mathrm{~cm}^{-1}$ were assigned to the $v(\mathrm{As}-\mathrm{O})$ and $(\mathrm{Cr}-\mathrm{O})$ stretching vibration respectively $[12,17]$ (see Fig. 8) confirming uptake of these species in the QHECE.

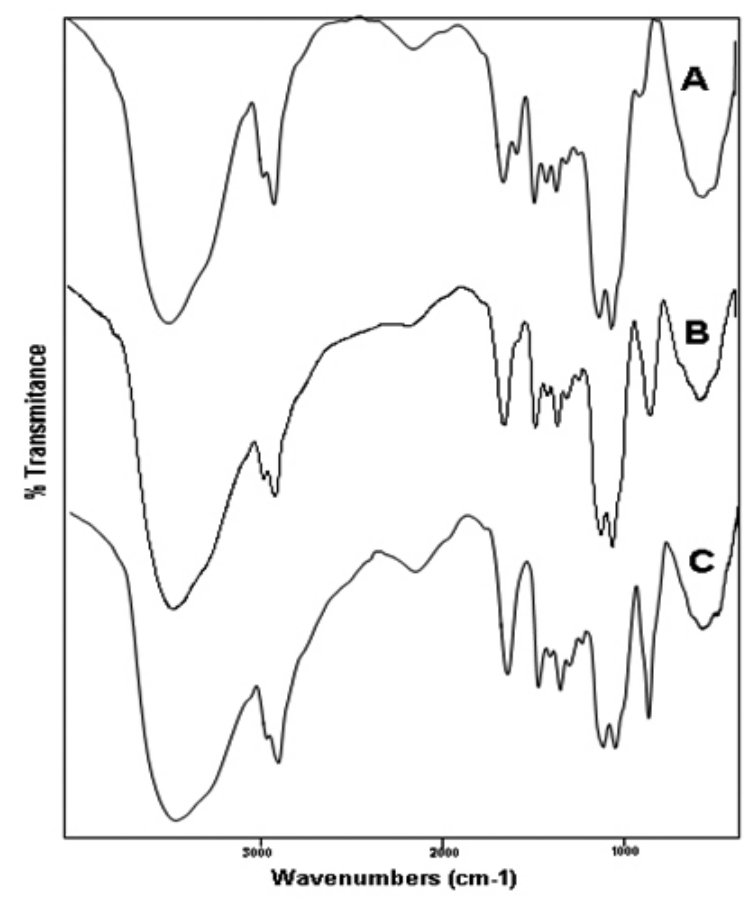

Figure 8. FTIR spectrum of (a) QHECE (initial sample), and (b) QHECEarsenic (V), (c) QHECE-chromium (VI), after determining the maximum retention capacity at $\mathrm{pH} 9$.

\section{CONCLUSIONS}

This study demonstrated the retention capacity of the soluble polymer QHECE for $\mathrm{As}(\mathrm{V})$ and $\mathrm{Cr}(\mathrm{VI})$, using LPR. The removal of arsenate and chromate ions was optimized through analysis of variables such as the $\mathrm{pH}$, the amount of polymer and the concentration of $\mathrm{As}(\mathrm{V})$ and $\mathrm{Cr}(\mathrm{VI})$. It was determined that retention was optimal at $\mathrm{pH} 9$, the optimum amount of polymer for the removal of arsenic was $75 \mathrm{mg}$, and for chromium it was $50 \mathrm{mg}$. The best results were achieved using a concentration of $15 \mathrm{mg} / \mathrm{L}$ of $\mathrm{As}(\mathrm{V})$ and $\mathrm{Cr}(\mathrm{VI})$. By means of the enrichment method we determined the maximum retention capacity of the polymer. FTIR spectra before and after of retention showed differences by the interaction with oxy-anions.

The results show the possibility of using cellulosic materials as a basis for obtaining water-soluble polymers capable of retaining oxyanions such as chromate and arsenate. Functionalization and increasing the solubility of cellulose seem feasible ways in environmental applications.

\section{ACKNOWLEDGMENTS}

The authors are grateful for grants from FONDECYT (Grant No 1110079), REDOC (MINEDUC, Proyect UCO 1202 of Universidad de Concepción), and PIA (Grant Anillo ACT-130). Julio Sánchez thanks FONDECYT (postdoctoral Grant No 3120048) and CIPA.

\section{REFERENCES}

1. N. Lavoine, I. Desloges, A. Dufresne, J. Bras, Carbohyd. Polym. 90, 735, (2012)

2. T. Heinze, A. Koschella, Polymer 15, 84, (2005)

3. M. Lia, Y. Qia, Y. Dinga, Q. Zhaoa, J. Feia, J. Zhoub, Sensor Actuat B-Chem. 168, 329, (2012)

4. B.L. Rivas, E.D. Pereira, M. Palencia, J. Sánchez, Prog. Polym. Sci. 36, 294 (2011)

5. B.L. Rivas, K. E. Geckeler, Adv. Polym. Sci. 102, 171 (1992)

6. Y. Li, M. Wu, R. Liu, Y. Huanga, Sol. Energ. Mat. Sol. C. 93, 1321 (2009)

7. K. Wang, L. Ye, Polym-Plast. Technol. 49, 807 (2010)

8. W. Gao, X.M Liu, R.A Gross, Polym. Int. 58, 1115 (2009)

9. C.H. Niu, B. Volesky, D. Cleiman, Water Res. 41, 2473 (2007)

10. D. Ranjana, M. Talatb, S.H. Hasana, J. Hazard. Mater. 166, 1050, (2009) 
11. J. Saikiaa, B. Sahab, G. Dasa, J. Hazard. Mater.186, 575 (2011)

12. L. Toledo, B.L. Rivas, B.F. Urbano, J. Sánchez, Sep. Purif. Technol. 103, 1 (2013)

13. B.L. Rivas, E. Pereira, I. Moreno, Progr. Polym. Sci. 28, 173 (2003)

14. B. Chaufer, A. Deratani, Nucl. Chem. Waste Managm. 8, 175 (1988)

15. J. Sánchez, B.L. Rivas, E. Nazar, M. Bryjak, N. Kabay. J. Appl. Polym Sci. 162, 1541 (2013).

16. J. Sánchez, B.L. Rivas, Chem. Eng. J. 165, 625, (2010)

17. B.L. Rivas, E. Pereira, R. Cid, K.E. Geckeler, J. Appl. Polym. Sci. 95, 1091 (2005).

18. B. L. Rivas, E. D. Pereira, M. Palencia, J. Sánchez, Prog. Polym. Sci. 36, 294 (2011).
19. K. E. Geckeler, R. Zhou, B.L.Rivas, Angew. Makromol. Chem. 197, 107 (1992)

20. I. Bodek, W.J. Lyman, W.F. Reehl, D.H. Rosenblatt, Environmental Inorganic Chemistry: Properties, Processes and Estimation Methods, Pergamon Press, USA, 1998.

21. P.L. Smedley, D.G. Kinniburgh, Sources and behaviour of arsenic in natural water, Chapter 1 in United Nations Synthesis Report on Arsenic Drinking Water, 2005

22. I. Moreno-Villoslada, B.L. Rivas, J. Phys. Chem. B. 106, 9708 (2002)

23. P. Marel, A. Zwijinenburg, A. Kemperman, M. Wessling, H. Temmink, W. Meer, J. Membrane Sci., 332, 24 (2009) 